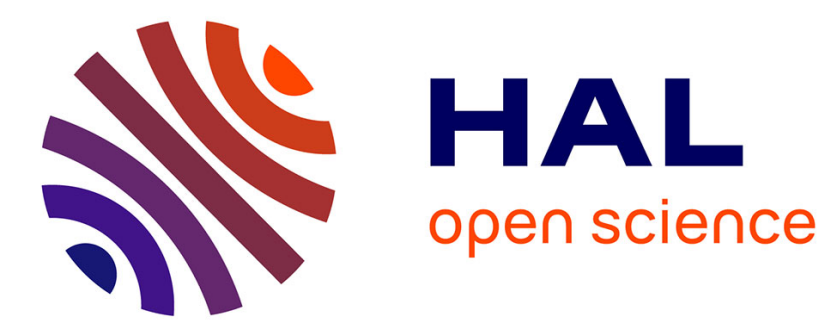

\title{
Performing the Curmudgeon: The Toothless Lion
}

Charles Holdefer

\section{To cite this version:}

Charles Holdefer. Performing the Curmudgeon: The Toothless Lion. Culture, Society \& Masculinities, 2011, vol. 3 ( $\left.\mathrm{n}^{\circ} 1\right)$, p. 62 - 73. 10.3149/CSM.0301.62 . hal-01643552

\section{HAL Id: hal-01643552 https://hal.science/hal-01643552}

Submitted on 14 Dec 2017

HAL is a multi-disciplinary open access archive for the deposit and dissemination of scientific research documents, whether they are published or not. The documents may come from teaching and research institutions in France or abroad, or from public or private research centers.
L'archive ouverte pluridisciplinaire HAL, est destinée au dépôt et à la diffusion de documents scientifiques de niveau recherche, publiés ou non, émanant des établissements d'enseignement et de recherche français ou étrangers, des laboratoires publics ou privés. 


\section{Performing the Curmudgeon: THE TOOTHLESS LION}

Growing old is a process of reinvention. Performing the curmudgeon is one way to redefine dignity in a time of waning powers. The curmudgeon trades in earlier roles of authority and virility and, by repositioning himself above the fray, creates a new space where he can perform. This paper draws on J.L. Austin's notion of performative utterances and explores how they can coalesce to form a persona which becomes a functioning gender parody (J. Butler) and participate in a broader dynamic of masculinities (R.W. Connell and J.W. Messerschmidt). After defining the curmudgeon, this paper considers two "case studies:" the comedian George Carlin and the poet Philip Larkin, in light of issues of chronology, space, sexuality and the creation of a "post-virile" status. Lastly, it addresses the political coding of the curmudgeon and its future as a masculine parody.

Keywords: Aging, Masculinity, Curmudgeon, Performance, Parody

The curmudgeon is not an obscure or esoteric figure, but his importance for male role-playing, particularly for aging males, is underestimated and has not been sufficiently explored. Judith Kegan Gardiner has observed that age remains an undertheorized category in comparison to gender and, in addition to being biologically and socially constructed, it is also performative (2002, pp. $93,96)$. The curmudgeon is a case in point. Performing the curmudgeon is a sort of survival strategy, a way to redefine dignity in a time of waning powers. The curmudgeon trades in earlier male roles centered on virility and competi-

* Département d'Etudes Anglophones, Université de Poitiers, France.

This article is based on a paper read at the conference "Performing the Invisible: Masculinities in the English-Speaking World," Université Sorbonne Nouvelle-Paris 3, September 25-26, 2010. Research was supported by the FORELL, Université de Poitiers, and Université Paris 3-Sorbonne Nouvelle. The author is grateful to Claire Conilleau, Hélène Quanquin, Ariane Blayac, and Claire Delahaye for their helpful editorial comments on earlier drafts of this article.

Correspondence concerning this article should be addressed to Charles Holdefer, Département d'Etudes Anglophones, 1 rue Raymond Cantel, BP 613, 86022 Poitiers, Cedex, France. Email: charles.holdefer@univ-poitiers.fr

Culture, Society E Masculinities, Volume 3 Issue 1, 2011, pP. 62-73.

ISSN 1941-5583 (PRINT) 1941-5591 (ONLINE) • CSM.0301.62/\$15.00・DOI: 10.3149/CSM.0301.62 Copyright (C) 2011 by the Men's StUdies PRESS, LLC • HTtP://WWW.MENSSTUdies.COM 
tion $^{1}$ and, by an act of repositioning himself above the fray, creates a new space where he can perform.

I view the curmudgeon in this manner by drawing on an appreciation of how performative utterances (Austin, 1982) can coalesce around a persona which, if sufficiently stylized and recognizable through repetition, can become a functioning gender parody (Butler, 1990) and participate in a broader dynamic of masculinities (Connell \& Messerschmidt, 2005). ${ }^{2}$ These performative utterances need not be seen as conveying metalinguistic truths (Terada, 1995). The point is the effect.

The curmudgeon is often valued for his straight talk and frankness, but he is not playing a "parrhesiastic game" as described by Michel Foucault, for whom power is the focus (2001). He is no Socratic interrogator, and he would probably harrumph at the mention of Michel Foucault. He does not put himself in danger, nor does he constitute a threat. The curmudgeon is, in effect, a toothless lion.

This fact does not, however, condemn him to irrelevance. In a world full of cant and hypocrisy, the curmudgeon offers the appearance of alternatives. His performance distances itself from younger versions of masculinity and, at times, can involve its audience in a sort of Brechtian estrangement. He also shares some of the traditional features of The Fool.

Who, exactly, is a curmudgeon? In order to underline the pervasiveness of the figure, this discussion will draw on examples from a wide range of sources: literature, stand-up comedy, biography and popular culture, which can all be viewed as performative utterances, ${ }^{3}$ and which constitute, by their repetition in so many contexts, a readily recognizable masculine parody. I will begin with a tentative definition of the curmudgeon, emphasizing its dependence on a social contract, and then I shall consider two "case studies:" the comedian George Carlin and the poet Philip Larkin. I have chosen Carlin and Larkin because each was widely recognized by major media and cultural commentators as curmudgeons, ${ }^{4}$ and because studying them will open the discussion to both Amer-

${ }^{1}$ For instance, the jock, lover, leader, dad, etc.

${ }^{2}$ Connell and Messerschmidt (2005) emphasize a plurality of masculinities which are evolving "configurations of practice," which can be "hegemonic" or "nonhegemonic." The curmudgeon would belong to the latter category.

${ }^{3}$ Austin focuses on performative utterances as "conventional procedure having a certain conventional effect" (p. 14), while considering theater or poetry as "hollow" language, which is "parasitic upon its normal use" (p. 22). Butler underlines the "critically queer" potential of the latter category, referred to as "illocutionary performatives" (1993, p. 214n). My discussion will include the entire range of performatives, whether "ordinary" or "illocutionary," treating them as functionally constitutive elements of the curmudgeon.

${ }^{4}$ Carlin was "the comedy circuit's most splenetic curmudgeon" according to his New York Times obituary (Watkins \& Weber, 2008), while J.D. McClatchy's extended review of Larkin's Collected Poems was entitled "Songs of a Curmudgeon" (1989). These are typical descriptions of the men. 
ican and British contexts, which is desirable at this stage of description. Although this article cannot pretend to be exhaustive, Carlin and Larkin are in many ways representative and complement each other in regard to key performative contours. ${ }^{5}$ Carlin's career illustrates issues of chronology and space, while close readings of several Larkin poems provide insights about the curmudgeon's sexuality or "post-virile" status. Lastly, this article will address the problematic political coding of the curmudgeon, and consider its future as a masculine parody in the $21^{\text {st }}$ century.

\section{DEFINING A CURMUDGEON}

The etymology of "curmudgeon" is unknown and a matter of speculation. Samuel Johnson gave the derivation as "coeur méchant" from an unknown correspondent (1755). Some speculate that it has Scottish origins from a word meaning to mumble or grumble (Winokur, 2007, p. 20), and today it is a common translation of the Irish and Scottish Gaelic "bodach," which is a kind of hobgoblin. Dictionaries variously define the curmudgeon as a bad-tempered, cantankerous person, or as a miser, grouch or sourpuss.

Of course, a curmudgeon does not have to be a straight white male, though that is indeed the most common received image, or performance of the role, in the English-speaking world. It is easy to think of other configurations: in contrast with straight, there is the example of a person like Quentin Crisp, or a long tradition of drag queens appreciated for their waspish comments, some of which could be characterized as curmudgeonly. In contrast with white, there is the African-American cultural critic Stanley Crouch, sometimes referred to as "Crouch the grouch" (Alexander, 1999), or the comedian Redd Foxx. In contrast with male, there have been mass market anthologies such as The Curmudgeon Woman, which featured Margaret Thatcher, Gloria Steinem and Phyllis Diller on its cover-an unlikely trio in other contexts-united, supposedly, by their shared curmudgeonliness (Henley \& Goodchilds, 2000).

That said, homosexual curmudgeons and queer alternatives have been given less space in the cultural conversation, while racial groupings have historically been rooted in other received images and stereotypes. For the elderly black man, there is the figure of "uncle;" elderly Asians have been often cast in the mould of wise man or guru, and Native Americans as the tragic vanishing Indian or cryptic shaman. And for cranky old women, instead of "curmudgeon," the words more commonly used have been shrew, crone, hag, harridan, harpyall of them gender-specific and negative, though there have been recent efforts of feminists to re-examine them (Henley \& Goodchilds, 2000, p. vii).

For contemporary usage (and marketing) of the curmudgeon, one can turn to Jon Winokur. Winokur is the editor of popular anthologies like The Portable

${ }^{5}$ That said, I am not in pursuit of a transnational or "essential" curmudgeon. Geography, history and the individual psyche play crucial, particularizing roles in the ongoing dynamic of masculinities. This essay is intended as a general introduction. 
Curmudgeon, The Traveling Curmudgeon and The Big Curmudgeon. He is arguably the dean of the current curmudgeon industry in mainstream American publishing. Like the anthology of curmudgeon woman, these works are not scholarly sources but they are symptomatic of the culture. Winokur sums up the range of definitions neatly. A curmudgeon is "A crusty, ill-tempered, churlish old man; 2 . Anyone who hates hypocrisy and pretense and has the temerity to say so; or 3. anyone who points out unpleasant facts in an engaging and humorous manner" (Winokur, 2007, p. 7).

Historically, the first two definitions have dominated. The rise of the last definition reflects recent reassessments of gender roles, and is perhaps also a reaction to earlier rhetorical excesses about positive thinking. Curmudgeons, in fact, occupy a now-fashionable niche. Grumpy Old Men, a BBC Two program which began in 2003, quickly led in 2004 to Grumpy Old Women, which ran for several seasons, was repackaged as a book and stage show, and is still used as a theme for holiday television specials. A cursory Internet search reveals blogs not only with names like "The Crusty Curmudgeon," which fits the traditional mould, but also "The Young Curmudgeon," "The Precocious Curmudgeon" and "The Knitting Curmudgeon," to name a few. It has been commercialized to the point that a company sells curmudgeon greeting cards. ${ }^{6}$

I will speculate later about the future of the curmudgeon in light of such departures from the traditional gender parody; my principal interest here is to explore the workings of the aging masculinist model, which involves a particular kind of social contract, or trade-off. Tellingly, the curmudgeon has no enforceable authority. One does not have to submit to this bad-tempered or surly old person. Rather, his performance can be enjoyed (or ignored) by his listeners as a construct in itself. In some respects, the curmudgeon's position is analogous to the traditional idea of putting a woman on a pedestal. It is an appreciation which is premised on powerlessness. But, in his case, it is less a matter of gaze than of listening, to the toothless lion's roar.

The typical appeal of this performance is that the curmudgeon seemingly knows how to do away with equivocation, excuses, and wishy-washy attitudes. Consider this example from the cowboy poet Wallace McRae, in the appropriately titled "The Cowboy Curmudgeon":

You lookin' for candor? Well, canned you done got.

I'll wash all the wishys 'n hang 'em up high.

You're yearnin' for truth? Well like it or not,

I'll render your gizzard and show it the sky. (1992, p. 136)

The tone is unapologetically aggressive. The image is revealing, too: "render your gizzard" (emphasis added). In other circumstances, a listener probably would not tolerate this kind of speech. As a rule, we are very attached to our gizzards, and we do not like someone probing them or putting them on display. But, for the curmudgeon, we will make an exception, because age has obliged him to trade in his power and we know that he is physically innocu-

${ }^{6}$ See http://www.curmudgeoncards.com/company.html. 
ous and cannot really hurt us. If he could, we (or a younger, stronger, more powerful person) would probably shun him for his unpleasantness, ignore him, or fight back and supplant him. Rather, as the gizzard image suggests, with a large degree of literalism, the appeal of the curmudgeon is visceral.

Of course, no sane person would want to live with W.C. Fields, or at least with the persona he projected, but the idea of a crank who hates dogs and small children has a certain charm. (This charm, of course, is highly contextual, and need not be appreciated at all times by everyone.) When H.L. Mencken says, "Every normal man must be tempted, at times, to spit upon his hands, hoist the black flag, and begin slitting throats" (1919), or, when Mark Twain says, "[God] takes no interest in man, nor in the other animals, further than to torture them" (1996, p. 327), they touch a nerve that we might like having touched. Scrooge, most readers would agree, is more entertaining than Tiny Tim.

\section{George CarLin:}

\section{From CoOl to Cranky, or A Curmudgeon's Progress}

George Carlin (1937-2008) offers an interesting case study because his highly public life illustrates the aging process and trajectory toward a curmudgeonly performance space. ${ }^{7}$ A highly popular stand-up comedian and occasional actor and author, Carlin was a familiar face on American stage and television for five decades. A common thread through all the phases of his career was a love of words and the playful possibilities of language and, beyond his role as an entertainer, he left his mark on American jurisprudence about censorship when a suit related to his famous 1972 stand-up routine, "Seven Words You Can Never Say on Television" got him arrested, and the 1973 radio broadcast of a related routine resulted in a lawsuit that eventually went to the United States Supreme Court, and a ruling on the F.C.C.'s authority to regulate such broadcasts (Federal Communications Commission v. Pacifica Foundation, 438 U.S. 726 (1978)).

Carlin began as a fairly conventional stand-up comedian, but by the 60 s and 70 s, he had evolved into a high profile countercultural figure. He sported a beard and long hair and cultivated a laid-back hippie image, creating characters like Al Sleet, a perpetually stoned television weatherman, and Scott Lame, a dippy disc jockey for the radio station "wonderful WINO." Although his routines contained political references typical of the Vietnam era, and his "Seven Words You Can Never Say on Television" was a rallying point for free speech advocates, Carlin was not, at this stage, conspicuously ideological or committed, and he certainly did not sound angry; his prevailing attitudes were "hipper than thou" or anarchically goofy. The famous "Seven Words" were released on his album Class Clown (1972) which, as the title suggests, is hardly a manifesto. The routine features Carlin reciting the seven words very quickly

${ }^{7}$ Born in Manhattan, Carlin was a high school dropout who served in the U.S. Air Force and worked as a disc jockey before pursuing a career in comedy. He was awarded The Mark Twain Prize for American Humor in 2008. 
in the manner of a tongue-twister, a stunt that was imitated by schoolchildren across America, not just for the predictable pleasure of violating a taboo, but also because tongue-twisting was fun, a competitive diversion for kids. ${ }^{8}$ In this period of rock ascendancy and youth culture, the perception of being old was itself a taboo. ${ }^{9}$

Thus it was by no means obvious that in later years Carlin would become a ranter and fulminator, perhaps the most high profile curmudgeon entertainer of the last decade. There is not space here to discuss particular routines in detail, but a cursory review of his album and DVD titles tells the story: in the playful 1970s, these included FM \& AM (1972), Class Clown (1972), Occupation Foole (1973), and Toledo Window Box (1974). In the final dour decade of his life, he released You Are All Diseased (1999), Complaints and Grievances (2001), Life is Worth Losing (2006) and It's Bad For Ya (2008). Monologue subjects in the last one include "Traffic Accidents," "The All-Suicide TV Channel," "Coast-to-Coast Emergency," and, quoted below, "You Have No Rights."

Boy, everyone in this country is always running around yammering about their fucking rights. 'I have a right. You have no right. We have a right. They don't have a right.' Folks, I hate to spoil your fun, but you have no rights, OK? They're imaginary. We made them up. Like the Boogie Man. The Three Little Pigs. Pinocchio. Mother Goose. Shit like that. Rights are an idea, they're just imaginary. Cute idea, cute, but that's all: cute and fictional. ... I feel, for instance, that I have the right to do anything I please. But, if I do something you don't like, I think you have the right to kill me. So where are you going to find a fairer fucking deal than that?

Carlin's evolution from joker to misanthrope underlines that there is no necessary or inevitable link between the curmudgeon and younger nay-sayers, such as the "Angry Young Man." It would be temptingly logical to assert a chronology according to which Angry Young Men grow up to be curmudgeons, but there are too many counter-examples. For every Kingsley Amis, who would seem to follow a trajectory from Angry Young Man to curmudgeon, there is someone like Henry Miller, who, after being hardboiled, in his later years became a New Age Softie. Probably more useful than chronology in this regard is the idea of a curmudgeonly space. Although discussions of "masculine" space have often focused on consumption (Mort, 1996), shared geographies (Hörschelmann \& Van Hoven, 2004) and male bonding (Twitchell \& Ross, 2006), here I am addressing examples that are more self-consciously individualistic. The Angry Young Man is usually some sort of rebel, loner, or outsider. But there is a difference between positioning oneself outside, or (as in the case

\footnotetext{
${ }^{8}$ In one breath, without pause: "shitpissfuckcuntcocksuckermotherfuckerandtits."

${ }^{9}$ Rock typically addresses the curmudgeon with a pirouette: rather than foregrounding the performer's advanced years and self-identification as a curmudgeon, a song is more likely to be about a curmudgeon (e..g., the Beatles' "Mean Mr. Mustard" or a travesty of the role (e.g., Nirvana's "Curmudgeon").
} 
of the curmudgeon) above. The outsider is often on a quest for alternatives; the curmudgeon has less time, and is probably settling for the satisfactions of shaking his fist at the world.

To what effect? When Carlin holds forth about powerlessness and the arbitrary nature of "rights," he both talks tough and at the same time makes it manifestly clear that he is not the man in charge. He becomes, in a manner, a weakened parody of masculine prerogative, even as he uses its ostensible weaponry, expressing himself in extravagant outbursts of anger. In another context, the anthropologist Rosalind Morris (1995) has described the idea of "performing gender twice over" and has pointed to a number of possible effects. These effects include liminality, anti-structure, play, and even (though she suggests that this is more rare) a Brechtian estrangement, toward "a transcendence of the bastard mimesis with a 'truer,' more 'adequate,' or more 'liberating' mimesis" (p. 586). I would argue that the last example is the case here. While Carlin lets off steam about rights being made-up stories like Pinocchio, he also alerts his listeners to the theatricality of his pose. He becomes a subject objectified. And when this estrangement happens, a more critical appreciation of his role and of alternatives beyond it becomes possible.

Lastly, although such parodies and subterranean critiques of masculine power are not without pathos, the curmudgeon is not tragic, either. Carlin's musings on "Things We Say When People Die" and "Parents in Hell" are performed at a safe remove, for bitter laughs, and cannot be compared to the laments of Shakespeare's King Lear who, whether on the throne, on the heath or in prison, remains vulnerable, in the fray, often in the most elemental sense. Lear pays a high price for this vulnerability and comes to admit that his rages were the product of "a very foolish fond old man" (1608, 4.7.60). The curmudgeon, in contrast, is an irascible smart old man, who has managed to find shelter, paradoxically, on a proscenium.

\section{PHILIP LARKIN:}

\section{The Post-Virile Condition, or Life After SeX}

A generation after his death, the English poet Philip Larkin (1922-1985), my second case study, is still popularly remembered as a curmudgeon. ${ }^{10}$ In this era of compulsive rankings and lists, Larkin's Collected Poems was recently nominated by The Wall Street Journal as one of the "five best curmudgeonly books" for the writer's qualities as a "misogynist, child-hater and stone atheist" (Derbyshire, para. 5). This description is superficially accurate, as far as it goes, though critics have pointed out the performative, even campy aspect of Larkin's personae (Holdefer, 2006; Swarbrick, 1997) and his penchant for masking (Rácz, 1995). In this discussion I would like to narrow the focus to several

${ }^{10}$ Born in Coventry, Larkin was educated at Oxford and worked most of his adult life as a librarian at the University of Hull. Larkin published fiction and criticism but he is mainly remembered for his four volumes of poetry (The North Ship [1945]; The Less Deceived [1955]; The Whitsun Weddings [1964]; and High Windows [1974]). He was offered the position of Britain's Poet Laureate, but he declined. 
poems where the aging process is foregrounded (since, of course, misogyny, child-hatred and atheism can appeal to any age). I will emphasize particularly the "post virile status" and the performance of life after sex alluded to in the poems "Annus Mirabilis," "Posterity," and "This Be the Verse."

"Annus Mirabilis" (1968), whose title ironically echoes John Dryden's 1667 poem of the same name about military battles and the Great Fire of London, is emblematic of the curmudgeon's sexual predicament. In the famous first stanza, the speaker outlines his post-virile status in light of a larger cultural context:

Sexual intercourse began

In nineteen sixty-three

(which was rather late for me) -

Between the end of the Chatterley ban

And the Beatles' first LP. (p. 146)

Usually the poem is read as a comment on the so-called sexual revolution of the sixties, which was marked by changes in attitudes toward censorship with the open publication of works like Lady Chatterley's Lover, and the explosion of youth and popular culture, closely identified with the Beatles. The change, it seems, was inestimable. The second stanza describes the dreary, quarrelsome state of affairs before this era, before summing up a new existence where

every life became

A brilliant breaking of the bank,

A quite unlosable game.

So life was never better than

in nineteen sixty-three

(Though just too late for me)-

Between the end of the Chatterley ban

And the Beatles' first LP. (p. 146)

The speaker is clearly poking fun at the hype often attached to the swinging sixties and the rhetoric of liberation but, in the parenthetical comments, he also reveals something of himself. If we read these observations as representative of a curmudgeon's sex life, two facets emerge: first, the curmudgeon was untouched by the sexual revolution; and second, he is not troubled by this fact. There is little reason to take his claim about the "better" life in 1963 at face value. His is not an old-bachelor prudishness (which is itself a highly sexualized pose) but a matter-of-fact observation that he is no longer in the running. And implicitly, instead of regretting a post-sexual existence, he actually finds it a sort of relief. He avoids dissonance between biological age and self-perception, or between biological sex and self-defined gender (Gardiner, 2002, p. 95). The curmudgeon does not have to go along with the sexual revolution, which in any case will not deliver on such extravagant promises or fantasies. There is life after sex. 
On the other hand, there are limits to this defensive posture, and Larkin's poem "Posterity" (1968) underlines how the curmudgeon's post-virile status disempowers him with others. Here, the speaker's supposed biographer, a pushy American professor named Jake Balokowsky, takes over the poem after the first five lines and elbows himself into the spotlight for the remaining thirteen lines. Balokowsky describes the poet in purely exploitive terms, as just another step along the path of academic careerism. He disparagingly refers to him as an "old fart," a "bastard" and "one of those old-type natural fouled-up guys" (Larkin, p. 139). The italicization of "natural" calls attention to its own constructedness. According to Balokowsky, an "old-type natural fouled-up guy" lives a life devoid of interest. "He's not out for kicks or something happening." And this fact seems central to Balokowsky's lack of respect. ${ }^{11}$ It is the price the curmudgeon pays for taking himself out of the running. Another kind of male will be in charge.

Larkin offers, however, a post-virile riposte of sorts in "This Be The Verse" (1971) by raising the stakes and questioning the very idea of procreation. The performance here is very much a matter of form. Larkin's work is generally marked by an attention to traditional meter and rhyme, sometimes deployed very subtly. But the purposely clunky title of this poem signals another kind of game, and the first stanza flirts with doggerel.

They fuck you up, your mum and dad.

They may not mean to, but they do.

They fill you with the faults they had

And add some extra, just for you. (p. 142)

There is a difference, however, between playing the fool in the pedestrian sense and performing the courtly fool's role in the traditional sense, and I would argue that here Larkin is attempting something akin to the latter. The courtly fool not only entertains but also challenges norms or habits of thought. His role affords him a freedom of speech not enjoyed by other subjects of the king. Lear's fool, for instance, openly questions all appearances of natural and moral order. His only certainty is that "the rain it raineth every day" (1608, 3.2.77). Larkin adopts a similar tone in the last stanza of "This Be The Verse:"

Man hands on misery to man.

It deepens like a coastal shelf.

Get out as early as you can,

And don't have any kids yourself. (p. 142)

In real life Larkin was reluctant to make public statements or perform readings of his work ("I don't want to go around pretending to be me," Larkin,

11 The possible anti-semitic element in Larkin's characterization of Balokowsky further illustrates the problem of performed persona and authorial intention. See Motion (1993, p. 436). 
1983, p. 51) but what is striking in "This Be The Verse" is that Larkin concludes a poem with the kind of pronunciamiento that he professed to loathe. As in "Annus Mirabilis," the speaker goes beyond the immediate and local, and inserts himself into the history of humanity, with reference, even, to geologic time-whereupon he offers portentous advice. ("Get out as early as you can/And don't have any kids yourself.") The solution to human misery is to eliminate its source: humans. Here, the post-virile curmudgeon has the liberty to philosophize like a fool.

\section{CONCLUSION: \\ The Political Coding and Future of the Curmudgeon}

Given the often forceful expression of the curmudgeon's role, one could wonder about its political uses. Gardiner has noted how the shift from gender to age categories can "complicate, depolarize and contextualize" (2005, p. 167). Indeed, the curmudgeon's relationship to ideology is not simple.

It is a truism that the elderly are more likely to be conservative, and this has often been the case of curmudgeons. Within their respective contexts, figures like Evelyn Waugh and Philip Larkin (who were both fairly "old" even when they were "young"), or H.L. Mencken, probably fit that description. Kingsley Amis, earlier alluded to as someone who went from being a so-called Angry Young Man to being a curmudgeon, followed a trajectory of spending his early years as a member of the Communist Party, and his senior years as a supporter of Margaret Thatcher. The very notion of progress or the utopian impulse which underpins much of leftist thinking provides a number of tempting targets for the conservative curmudgeon. A forward-looking curmudgeon sounds like a contradiction in terms. What does a curmudgeon have to look forward to?

On the other hand, there is certainly no conservative monopoly. A respect for traditions and institutions, which underpins much of conservative thinking, provides tempting targets for the left-leaning curmudgeon. Brechtian estrangement, alluded to earlier, certainly had a leftish agenda, and individual curmudgeons like Edmund Wilson or George Bernard Shaw come to mind. George Carlin is probably best described as a libertarian, and writers like Edward Abbey or Edward Hoagland might be considered green curmudgeons. Ultimately, this right/left, conservative/liberal divide is too sweeping and simplistic, and the curmudgeon, as a gender parody, resists a specific political coding.

In the end, individuality trumps ideology, or, more precisely, an ideology of individualism prevails. Those of a partisan disposition can always find examples to make their case, but the Fool serves many kings. At times he can startle and estrange, and lead his listeners to question the established order but, most of the time, the role of the curmudgeon is as much about entertainment as wisdom. His words are valued for their asperity, not their profundity.

Such individualism is apparent in the recent rise of self-described curmudgeons who do not correspond to the traditional gender parody, whether young, female or some other male variant, such Larry David in the current HBO com- 
edy series Curb Your Enthusiasm, whose performance as "Larry David" shows an aging, semi-retired male whose narcissism is still a source of sexual tension and who, in spite of himself, cannot remain above the fray. David and other less traditional curmudgeons, in addition to testifying to the breadth of the curmudgeon's appeal, also demonstrate Connell and Messerschmidt's fundamental contention that "masculinities are configurations of practice that are constructed, unfold, and change through time" (2005, p. 852). The extent to which the role of the curmudgeon has become unmoored from its traditional masculinist usage remains uncertain, but perhaps we are entering an era where the kind of performance associated with him will cease to be a gender parody at all. In a more general context, Butler has referred to the process of "disidentification" (1993, pp. xiii, xiv), which might describe what is happening to the curmudgeon now.

At present, however, the traditional gender parody remains recognizable, and exists also as a spectral presence for other kinds of performers who have embraced the term. For the traditional curmudgeon, faced with aging, his defensive repositioning is also liberating. Since he no longer has to assume the responsibilities and images associated with masculine authority and virility, he can still find a role which provides gratification, though of a more limited, astringent sort. This trade-off comes at the price of power, and of being taken totally seriously, but it is a lively last stand before the final letting go, and death.

\section{REFERENCES}

Alexander, A. (1999, January 19). The bull in the Black-intelligentsia China shop. Salon.com. Retrieved from http://www.salon.com/bc/1999/01/19bc2.html.

Austin, J.L. (1982 [1955]). How to do things with words. Ed. J.O. Urmson \& M. Sbisà. Oxford: Oxford University Press.

Butler, J. (1990). Gender trouble: Feminism and the subversion of identity. New York: Routledge.

Butler, J. (1993). Bodies that matter: On the discursive limits of "sex". London \& New York: Routledge.

Carlin, G. (1972). Class clown. [LP Little David Records]. USA.

Carlin, G. (Dir.). (2008). It's bad for ya. [MPI Home Video]. USA, HBO.

Connell, R.W., \& Messerschmidt, J. (2005). Hegemonic masculinity: Rethinking the concept. Gender \& Society, 19(6), 829-859.

Derbyshire, J. (2010, June 12). Five best Books on curmudgeons. The Wall Street Journal Digital Network.

Federal Communications Commission v. Pacifica Foundation. (1978). 438 U.S. 726.

Foucault, M. (2001). Fearless speech. Los Angeles: Semiotext(e).

Gardiner, J. (2002). Theorizing age with gender: Bly's boys, feminism, and maturity masculinity. In J. Gardiner (Ed.), Masculinity studies and feminist theory (pp. 90-118). New York: Columbia University Press.

Henley, N., \& Goodchilds, J.D. (Eds.). (2000). The curmudgeon woman. Kansas City: Andrews McMeel.

Holdefer, C. (2006). Camping with Larkin. In A. McKeown \& C. Holdefer (Eds.), Philip Larkin and the Poetics of Resistance (pp. 67-80). Paris: 1'Harmattan. 
Hörschelmann, K., \& Van Hoven, B., (Eds.). (2004). Spaces of masculinities. London and New York: Routledge.

Johnson. (1755). A dictionary of the English language. London: J.F. and C. Rivington. Retrieved from http://www.archive.org/stream/dictionaryofengl01johnuoft\#page/n527/ mode/2up/search/curmudgeon

Larkin, P. (1983). Required writing. London: Faber \& Faber.

Larkin, P. (2003). Collected poems. London: Marvell Press and Faber \& Faber.

McClatchy, J.D. (1989, May 21). Songs of a curmudgeon. New York Times. Retrieved from http://www.nytimes.com/1989/05/21/books/songs-of-a-curmudgeon.html

McCrae, W. (1992). Cowboy curmudgeon and other poems. Salt Lake City: Gibbs-Smith.

Mencken, H.L. (1924). The New Poetry Movement. Prejudices, First Series (1919). New York: Knopf.

Morris, R. (1995). All made up: Performance theory and the new anthropology of sex and gender. Annual Review of Anthropology, 24, 567-592.

Mort, F. (1996). Cultures of consumption: Masculinities and social space in late twentieth-century Britain. London \& New York: Routledge.

Motion, A. (1993). Philip Larkin: A writer's life. London: Faber \& Faber.

Rácz, I. (1995). Agnosticism, masks and monologues in Philip Larkin. Hungarian Journal of English and American Studies, 1(2), 93-120.

Shakespeare, W. (1997 [1608]). King Lear. Ed. R.A. Foakes. London: Cengage.

Swarbrick, A. (1997). Larkin's identities. In S. Regan (Ed.), Philip Larkin (pp. 211-225). Basingstoke: Macmillan.

Terada, R. (1995). Austin and Antin about "about." Substance, 24(3), Issue 78, 49-69.

Twain, M. (1996). The Bible according to Mark Twain. Ed. H. Baetzhold \& J. McCullough. New York: Touchstone.

Twitchell, J., \& Ross, K. (2006). Where men hide. New York: Columbia University Press.

Watkins, M., \& Weber, B. (2008, June 24). George Carlin, comic who chafed at society and its constraints, dies at 71. New York Times. Retrieved from http://www.nytimes.com/2008/06/24/arts/24carlin.html?pagewanted=1

Winokur, J. (1992). The portable curmudgeon. New York: Plume.

Winokur, J. (2003). The traveling curmudgeon. Seattle: Sasquatch.

Winokur, J. (2007). The Big curmudgeon. New York: Black Dog \& Leventhal. 